\title{
Spatial variability of zooplankton community structure in Colombian Caribbean waters during two seasons
}

\author{
Johanna Medellín-Mora ${ }^{1,2}$, Rubén Escribano², Wolfgang Schneider ${ }^{2}$, Marco Correa-Ramírez ${ }^{3}$ \\ \& Nestor Campos ${ }^{4}$ \\ 1. Programa de Doctorado en Oceanografía, Universidad de Concepción, Chile; johanna.medellin@imo-chile.cl \\ 2. Instituto Milenio de Oceanografía (IMO) y Departamento de Oceanografía, Facultad de Ciencias Naturales y \\ Oceanográficas, Universidad de Concepción, Chile. P.O. Box 160, Concepción, Chile; \\ ruben.escribano@imo-chile.cl,wschneider@udec.cl \\ 3. Instituto de Investigaciones Marinas y Costeras - INVEMAR. Programa de Geociencias Marinas y Costeras; \\ marco.correa@invemar.org.co \\ 4. Instituto de Estudios en Ciencias del Mar - CECIMAR, Universidad Nacional de Colombia, Sede Caribe; \\ nhcamposc@unal.edu.co
}

Received 10-VIII-2017. Corrected 09-I-2018. Accepted 06-II-2018.

\begin{abstract}
Zooplankton is an important component to understand oceanographic dynamics, they are considered good indicators of environmental variability, since most species are short-lived they can be tight coupling of climate and population dynamics, and some taxa are sensitive to variables such as temperature, quality and quantity of food, oxygenation and stratification. In the Colombian Caribbean two oceanographic cruises were carried out, in order to characterize and analyze the biodiversity of the continental margin, for the periods May-June 2008 and November-December 2009. The objective of this study was to determine which oceanographic variable was the most important in the distribution of zooplankton in the oceanic waters, and how the variables structure the community. In each cruise, zooplankton samples were obtained by vertical hauls with a $1 \mathrm{~m}^{2}$ diameter conical net $(200 \mu \mathrm{m}$ mesh size). The zooplankton community structure was studied by automated image analysis (ZooImage), which combined with abundance data, allowed to calculate the slope of size spectrum, and diversity indexes of taxa and sizes. The environmental variables included temperature, salinity, oxygen and chlorophyll $a$ of the water column, and were used to calculate the stratification with the Brunt-Vaiisala frequency; this information was complemented by satellite images of temperature, surface chlorophyll, geostrophic currents and sea level, obtained from MODIS and AQUA products. The association between environmental variables and the zooplankton community structure was determined using Spearman's correlation ranges with the Bioenv routine and a stepwise regression model, and Principal component analysis (PCA). Our results showed spatial and temporal patterns in the oceanographic conditions of the study area, such as upwelling in the Northeast region, strong stratification in the Southwest, and mesoscale activity. The abundance of zooplankton exhibited differences between the two climatic seasons and zones. Temporal differences were also evident in the size and diversity of taxa (ANOVA 2-way $\mathrm{p}<0.05$ ). These changes were related to the moderate upwelling and the activity of mesoscale eddies. Cyclonic and anticyclonic eddies of variable size can either transport or retain zooplankton over cross-shelf and oceanic areas, thus modifying the taxonomic structure of the community. According to the Bioenv analysis, the main variables that explained the abundance and composition of zooplankton were sea level and chlorophyll $a$ (Spearman correlation $=0.49)$. The stepwise regression showed that stratification, oxygen and chlorophyll $a$ were the most important predictors of zooplankton abundance and size. Rev. Biol. Trop. 66(2): 688-708. Epub 2018 June 01.
\end{abstract}

Key words: size spectrum; mesoescale; stratification; distribution; mesozooplankton. 
Zooplankton are considered useful indicators of the impact of climate variability in the ocean environment, because they are composed mainly of short-lived species that respond rapidly to changes in their habitats, and thus, reflect the responses of the entire marine ecosystem (Beaugrand, Reid, Ibanez, Lindley, \& Edwards, 2002; Richardson \& Schoeman, 2004). Climate variability may in turn affect zooplankton habitats, altering their community structure and dynamics (Hays, Richardson, \& Robinson, 2005). The spatial patterns of community normally respond to spatial changes in the environmental (oceanographic) conditions, which determine ecological niches and the structure of the zooplankton in that habitat (Williams, 1988). Spatial patterns also reflect the effect of fish predation on zooplankton (Rand \& Hinch, 1998). To know how the zooplankton community structure changes spatially, under the different environmental conditions, may improve our capacity to predict changes in zooplankton in a future scenario of climatic change.

In the Northern region of Colombia, located in the Southwestern Caribbean, wind patterns respond to the shifting position (North -South) of the Intertropical Convergence Zone. Three seasons have been described for this region: a dry windy season (December to April), a transitional season (May to July), and a rainy season with low winds (August to November) (Andrade-Amaya, 2001). The westward-flowing Caribbean Current (Wüst, 1964; Morrison \& Nowlin, 1982), with its characteristically intense transit of mesoscale eddies, is the major oceanographic process in the Caribbean (Jouanno, Sheinbaum, Barnier, Molines, \& Candela, 2012). In the Northeastern zone off La Guajira Peninsula, winddriven upwelling events take place, stronger during the dry and transitional seasons, and weaker during the rainy season (Andrade \& Barton, 2005). The Central area is influenced by the Magdalena River, which discharges $7100 \mathrm{~m}^{3} \cdot \mathrm{s}^{-1}$ of fresh water, and contributes with $185 \times 10^{6}$ tons of sediments/year (Posada \& Henao, 2008). In the Southwestern zone, cyclonic circulation associated with the Panamá-Colombia Gyre is presented (Mooers \& Maul, 1998; Schott \& Molinari, 1996). This circulation generates the Panamá-Colombia countercurrent flowing East ward, which can reach La Guajira and Venezuela in the rainy season (Sheinbaum, Zavala, \& Candela, 1997; Andrade-Amaya, 2001; Andrade, Barton, \& Mooers, 2003).

The distribution and structure of the zooplankton community may be conditioned by the environment and its processes (physical and chemical). Temperature and food availability are known as major drivers of zooplankton dynamics (Hays et al., 2005; Escribano, Bustos-Ríos, Hidalgo, \& Morales, 2016). Mesoscale circulation can have a significant effect on the spatial distribution and structure of zooplankton communities (Praire, Sutherland, Nickols, \& Kaltenberg, 2012). For example, higher zooplankton productivity and abundance have been found at the center of cyclonic eddies, due to divergence and the rise of nutrient rich waters (López-Salgado, Gasca \& Súarez-Morales, 2000; Correa-Ramírez, Hormazábal, \& Yuras, 2007; Llinás, Pickart, Mathis, \& Smith, 2009). It has also been shown that eddies influence the local production and ecosystem dynamics, offering ecological niches for higer trophic levels (Chenillat, Franks, Riviére, Capet, Grima, \& Blanke, 2015). Other physical factors of the water column, such as, stratification and oxygen gradient showed influence on the structure of zooplankton (Medellín-Mora, Escribano, \& Schneider, 2016).

There have been few studies of the effects of climate variation on oceanographic processes, and the consequences for plankton dynamics and structure in the oceanic waters in the Caribbean. At a large scale, two expeditions in the Caribbean and adjacent waters described the horizontal and vertical distribution of zooplankton species related to water masses near Colombia (Park, 1970; Michele \& Foyo, 1976). These studies reported the greatest abundance in the Tropical Surface Water $(0-50 \mathrm{~m})$ and Subtropical Underwater (50 - $200 \mathrm{~m})$, although some species were reported as typical for 
Sub-Antarctic Intermediate (450 - $900 \mathrm{~m})$ and North Atlantic Deep Waters (>900 m). More recently, Medellín-Mora and Martínez-Ramírez (2010) observed that the major concentrations of organisms are in the Northern area, associated with the upwelling zone, and in the Southwestern area influenced by river runoff and the Panama-Colombia Gyre. Very little information is available on zooplankton size structure. Gutierrez (2011) found that small zooplankton dominates all water masses in the Caribbean, while larger and medium-sized zooplankton was scarce. Other studies have also examined the influence of the dynamics of the Caribbean on zooplankton community structure (Park, 1970; Owre \& Foyo, 1972; Michele \& Foyo, 1976; Franco-Herrera, Castro, \& Tigreros, 2006; Taylor et al., 2012).

Zooplankton community structures at different spatial and temporal scales have been efficiently assessed by automated methods like ZooImage (Irigoien, Fernandes, Grosjean, Denis, Albaina, \& Santos, 2009; Manríquez, Escribano, \& Hidalgo, 2009; Di Mauro, Cepeda, Capitanio \& Viñas, 2011; Manríquez, Escribano, \& Riquelme-Bugueño, 2012; Medellín-Mora et al., 2016). ZooImage can provide the size spectrum of a community, which is considered an important descriptor (Medellín-Mora \& Escribano, 2013). For example, variations in the size spectrum slope have been used to infer changes in spatial and temporal size structure under the influence of environmental factors (Lefort, Aumont, Bopp, Arsouze, Gehlen, \& Maury, 2015; Canales, Law, \& Blanchard, 2016), or in response to pollution, habitat alteration or exploitation (Robson, Barmuta, \& Fairweather, 2005; Shin, Rochet, Jennings, Field, \& Gislason, 2005; Gómez-Canchong, 2011). Therefore, the size spectrum slope, complemented with taxonomic composition, which ZooImage also assesses, should be considered a useful tool to study zooplankton responses to changes in the physical environment.

In the present study, we used automated analysis of zooplankton samples to assess the community size spectra, major taxa diversity and abundance in relation to spatial oceanographic variation for two seasons in the Colombian Caribbean, in pursuit of understanding how oceanographic dynamics, influenced by seasonal climatic conditions, affect the spatial structure of the zooplankton community.

\section{MATERIAL AND METHODS}

Study site: The study area is the oceanic waters of the Colombian Caribbean over a $900-\mathrm{m}$ isobath. A total of 36 stations were sampled, 13 during the transitional season between the dry and rainy seasons (May - June 2008), and 19 during the rainy season (NovemberDecember 2009) (Fig. 1). Oceanographic data were obtained with an autonomous CTD profiler (Idronaut Ocean Seven 316 plus) deployed down to near bottom at each station. Water samples were also collected with $10-\mathrm{L}$ Niskin bottles at five depths, 2, 50, 100, 150 and 200 $\mathrm{m}$ for chlorophyll- $a(\mathrm{Chl} a)$ analysis, conducted at the INVEMAR Environmental Quality Laboratory. Chl $a$ was measured by fluorometry following (Parson, Maita, \& Lalli 1984). These in situ measurements were used to calibrate the CTD fluorometer to obtain continuous chlorophyll- $a$ (Chla) profiles in the water column. Zooplankton samples were collected at each station by vertical hauls of a $1 \mathrm{~m}^{2}$ openingdiameter conical net (mesh size: $200 \mu \mathrm{m}$ ), equipped with a calibrated Hydro-bios flowmeter, and an opening-closing device. During the first campaign, samples were obtained from two depths: a) over the thermocline base or surface (after examining the temperature profile) and b) down the thermocline base to $200 \mathrm{~m}$. In the second campaign, samples were integrated from vertical tows from $200 \mathrm{~m}$ to the surface. Samples were fixed with $10 \%$ neutralized formalin in filtered seawater and stored for further observation and analysis in the laboratory.

Analysis of climate condition and oceanographic data: Rainfall data were provided by the Institute of Hydrology, Meteorology and Environmental Studies (IDEAM) from Coastal stations (on land) in the Colombian 

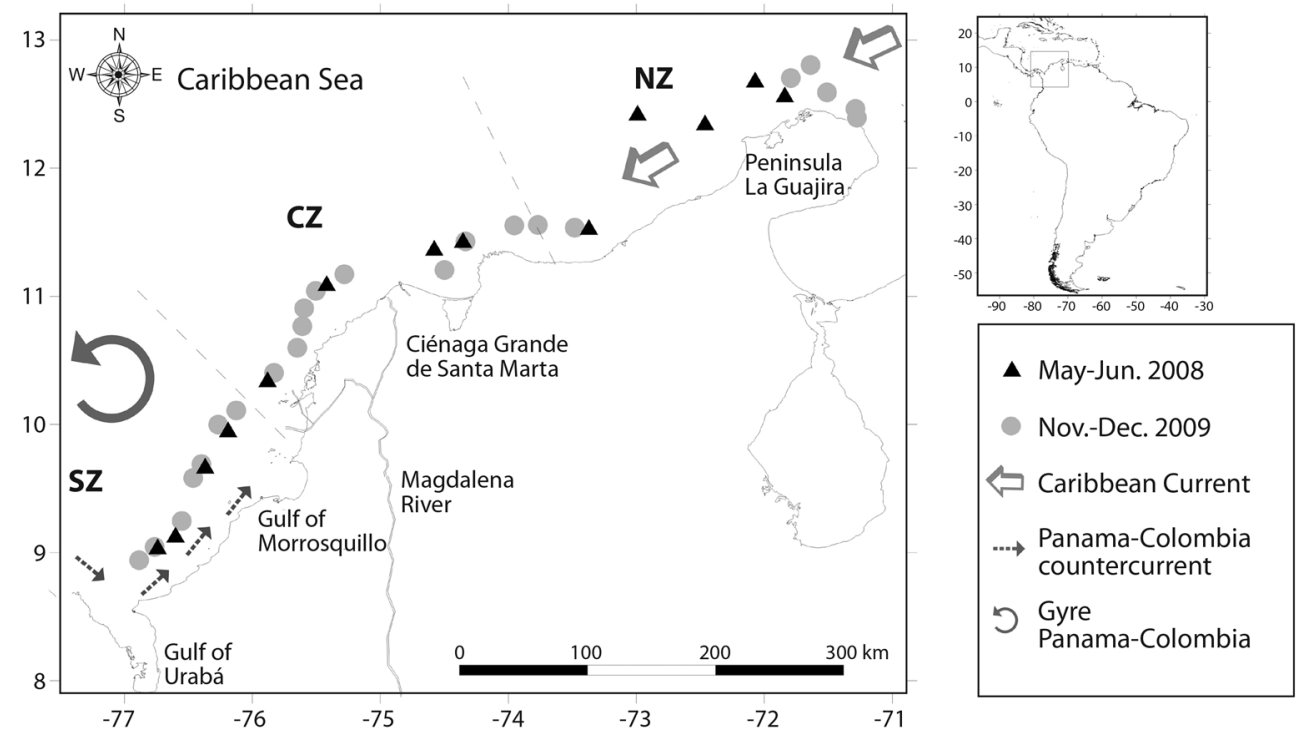

Fig. 1. Location of the stations in Colombian Caribbean during two seasons. Sectors used in this study: NZ: Northeastern Zone; CZ: Central Zone; SZ: Southwestern Zone.

Caribbean. Descriptive statistics (means, ranges, variations) were obtained for both seasons (May-Jun 2008 and Nov-Dec 2009). We tested differences in rainfall between zones and seasons (transitional vs rainy) after application of a two-way ANOVA with prior testing of variance homogeneity.

Other environmental variables used were Chla concentration derived from satellite information, sea surface temperature, sea level and geostrophic currents. Surface Chla and temperature data, with a spatial resolution of $4 \mathrm{~km}$, were obtained from level-3 products of the Moderate Resolution Imaging Spectroradiometer-MODIS - Aqua mission, distributed by the Ocean Biology Processing Group (http:// oceancolor.gsfc.nasa.gov/cms/). Data on sea level and geostrophic currents, were obtained from products of Saral, Cryosat-2, Jason-1\&2, T/P, Envisat, GFO, ERS-1 \& 2 and Geosat missions, distributed by AVISO (http://www. aviso.altimetry.fr/en/home.html). Average temperature and Chla were calculated between the first and last day of each cruise, using the geometric mean from available satellite records (without cloud interference). The sea level and geostrophic currents fields corresponded to the middle day of each cruise.

Field data from the oceanographic cruises were processed with the Gibbs Sea Water (GSW) Oceanographic Toolbox of TEOS-10 (IOC, SCOR \& IAPSO, 2010). We used absolute salinity, potential temperature, and in situ density to calculate the stability of the water column and the buoyancy or Brunt-Väisälä frequency (BVF), and potential energy anomaly (PEA) to assess stratification of the water column. We also looked at the temperature at $10 \mathrm{~m}$ depth and estimated the mixed layer depth (MLD) by considering the density gradient and the first higher value as the base of the MLD. Finally, we calculated the average temperature and oxygen of the mixed layer. In situ Chl $a$ in the water column, integrated in the upper $150 \mathrm{~m}$, was also included.

Analysis of zooplankton samples: Zooplankton samples were fractioned with a Folsom splitter in the laboratory of the Colombian Natural Marine History Museum (MHNMC). Most samples were subjected to fractioning, because of the presence of large numbers of 
small copepods. Fractioning ranged between $1 / 2$ and up to $1 / 64$. In addition, a size fractioning was applied to facilitate scanning samples using a $1000-\mu \mathrm{m}$ sieve to obtain two size fractions $(<1000 \mu \mathrm{m}$ and $>1000 \mu \mathrm{m})$. Sorting into two size fractions provided better spreading of samples for scanning, and prevented organisms overlapping. Both size fractions were scanned and then added by ZooImage. Before scanning, the sub-samples were stained with $5 \%$ Eosin. Excess colorant was removed with $70 \%$ ethanol (24 h exposure). The stained samples were placed on transparent acrylic plates $(26 \times 15$ $\mathrm{cm})$ and digitized with an EPSON Perfection V300 Photo scanner (800 dpi resolution). Digital images were then processed with ZooImage V1.2- software.

ZooImage processing requires a library of identified organisms (training set) to identify and count all the samples, so that using the same digital images we first built a training set for the study area, including the major zooplankton groups. A total of 15 taxa were selected (shown in Supplemental Material), of which copepods were the most abundant and covered a wide size range. Taxonomic identification was carried out using the Random Forest algorithm, evaluated using the 10-fold cross validation confusion matrix. This allowed us to determine the rate of error between manual (human eye) and automatic recognition, which resulted in an estimated accuracy of $80 \%$. Data on total abundance, taxonomic group identity, and size (measured as equivalent circular diameter, ECD), were obtained for each object in the digital images. ECD estimations were then used to obtain the size spectrum for each sample. Detailed procedures of ZooImage can be found in Grosjean and Denis (2007).

In addition to ZooImage analysis, traditional analysis under a stereomicroscope was used as to identify dominant copepod species. Copepods dominated all samples, and therefore, changes in species composition were important to provide further insight into community responses to oceanographic variation. This analysis was done with a fraction of each sample, similar to the one used for ZooImage, and it was made only for the first cruise (May-Jun 2008).

Analysis of zooplankton data: Stratified samples (13 of 36) were treated separately, but abundances were averaged over the $0-200 \mathrm{~m}$ water column. Abundance of zooplankton was calculated by ZooImage using the metadata (volume of filtered seawater, fraction of samples and size of the scanning dish) and then standardized as individuals. $\mathrm{m}^{-3}$. The size spectra for the zooplankton community were obtained from the data on taxa abundance and ECD estimates. These were first $\log _{2}$ normalized and then a simple model I regression analysis was applied. We used the slope (b) of size spectra as an index of the size structure of the zooplankton community. Moreover, we calculated the Shannon-Wiener diversity index for size class diversity (H'sc) and for major taxa diversity weighed by size (H'ts). $H^{\prime} s c=\Sigma p_{i} \operatorname{Ln}\left(p_{i}\right)$, where H'sc $=$ size class diversity, $\mathrm{pi}=$ the proportion of each i size class and $\mathrm{k}=$ total number of size classes. $\mathrm{H}^{\prime} \mathrm{ts}=\Sigma \mathrm{p}_{\mathrm{j}} \operatorname{Ln}\left(\mathrm{p}_{\mathrm{j}}\right)$, where $\mathrm{H}^{\prime}$ ts $=$ taxa diversity, $p j=$ the proportion of each $\mathrm{j}$ taxa weighed by its corresponding median size, and $\mathrm{T}=$ total number of taxa. Total identified taxa are shown in the confusion matrix (see Supplemental Material).

We tested for differences in the size spectrum slope and size class abundances with ANOVA. We also tested the effect of seasons and different zones of the Colombian Caribbean: Northeastern (upwelling influence), central (discharge river influence) and Southwestern (cyclonic gyre). Finally, multivariate analyses were conducted with PRIMER v.6 (Clarke \& Gorley, 2006). To do this, we first grouped different stations according to oceanographic variables using the ordination method of principal component analysis (PCA), based on Euclidean distance with standardized data. To assess similarities in the composition and abundance of the community among stations, we applied cluster analysis and multidimensional scaling (MDS) with logtransformed data and following Taylor's power 
law for aggregated data (Taylor, 1961). To do this, we used the Bray-Curtis index and average linking. Two factors were examined: temporal effects (climatic periods) and spatial effects (Northeastern, central and Southwestern). The ANOSIM routine was applied to test these effects, under the hypothesis that community composition and the abundance of zooplankton did not differ significantly between seasons and zones. Differences or similarities between groups were then analyzed with the SIMPER module (similarity percentages).

Finally, a bio-environmental analysis was applied to determine the combinations between environmental variables and the biotic component, expressed by the Spearman's rank correlation coefficient. In this analysis, the similarity matrix of zooplankton categories was correlated to the abiotic similarity matrix (Euclidean distance) to find the set of variables with the best correlation (Clarke \& Warwick, 2001). Similarly, with the SYSTAT-12 program, stepwise regression modeling was carried out on the data sets collected in the two seasons (May 2008 and November 2009). Dependent variables (abundance of zooplankton, the size spectrum slope and diversity index) were related to independent variables (stratification, temperature, oxygen, Chla and Sea Level Anomaly). The stepwise regression analysis was particularly useful, as its algorithm uses partial correlations (thus minimizing problems with co-linearity) and helps to identify variables of greater importance (Krivtsov, Howarth, \& Jones, 2009).

\section{RESULTS}

Environmental variability: The coastal precipitation data for the 2008 and 2009 presented an annual mean rainfall of 132.2 and $111.7 \mathrm{~mm}$, respectively (Digital Appendices). Significant differences were found between years $(\mathrm{F}=16.46, \mathrm{P}=5.64 \mathrm{e}-05)$ and zones $(\mathrm{F}=$ $11.79, \mathrm{P}=9.54 \mathrm{e}-06$ ). In May-Jun 2008 (transitional season), the mean rainfall was 138.0 $\mathrm{mm}$, ranging between 13.3 and $426.8 \mathrm{~mm}$. In November 2009 (rainy season), the mean precipitation was $106.7 \mathrm{~mm}$, with a maximum of $364.4 \mathrm{~mm}$ and minimum of $11.75 \mathrm{~mm}$ (Digital Appendices). For the study periods only significant differences between zones were found $(\mathrm{F}=5.697, \mathrm{P}=0.001)$, but not between seasons $(\mathrm{F}=2.206, \mathrm{P}=0.141)$. Apparently, both seasons were transition periods and for this study were designated as transition 1 (May-Jun 2008) and transition 2 (Nov-Dec 2009).

Sea level anomaly and estimated geostrophic currents derived from satellite information, revealed the presence of the large Panama-Colombia gyre during the two seasons, also with strong mesoscale activity (Fig. 2A and Fig. 2D). During the transition period (May-June 2008) a greater mesoescale activity was observed, with two large anticyclonic eddies offshore (beyond $200 \mathrm{~km}$ ) (Fig. 2A) in the Southwestern and Northeastern zones. There were two anticyclonic eddies, one in the Northeastern zone and the other in the Southwestern zone. The eddies converged closer to shore in the central zone during the rainy season (Fig. 2D).

There were marked differences in oceanographic surface conditions among zones and between seasons. Temperature was relatively low (ca. $25^{\circ} \mathrm{C}$ ) and Chla high $\left(>1 \mathrm{mg} \mathrm{m}^{-3}\right.$ ) in the transition season in the Northeastern zone, suggesting the presence of an upwelling event (Fig. 2B), which was not evident in the second period (Fig. 2E). Temperatures were high during both seasons in the Southwestern zone, although, also with high levels of Chla associated with an anticyclonic eddy and river discharges in the area. In the central zone the discharge of the Magdalena River formed $\sim 100 \mathrm{~km}$-long plume with high Chla (Fig. 2C and Fig 2F) and warmer water in both seasons (Fig. 2B and Fig. 2E). In situ oceanographic conditions obtained from vertical CTD profiles were used to construct a vertical section of temperature, salinity, oxygen, stratification and Chla through the Northeast-Southwest direction (Fig. 3).

The patterns of the vertical section of temperature were similar in the two seasons, with higher values $\left(>25^{\circ} \mathrm{C}\right)$ in the layer $0-150$ 

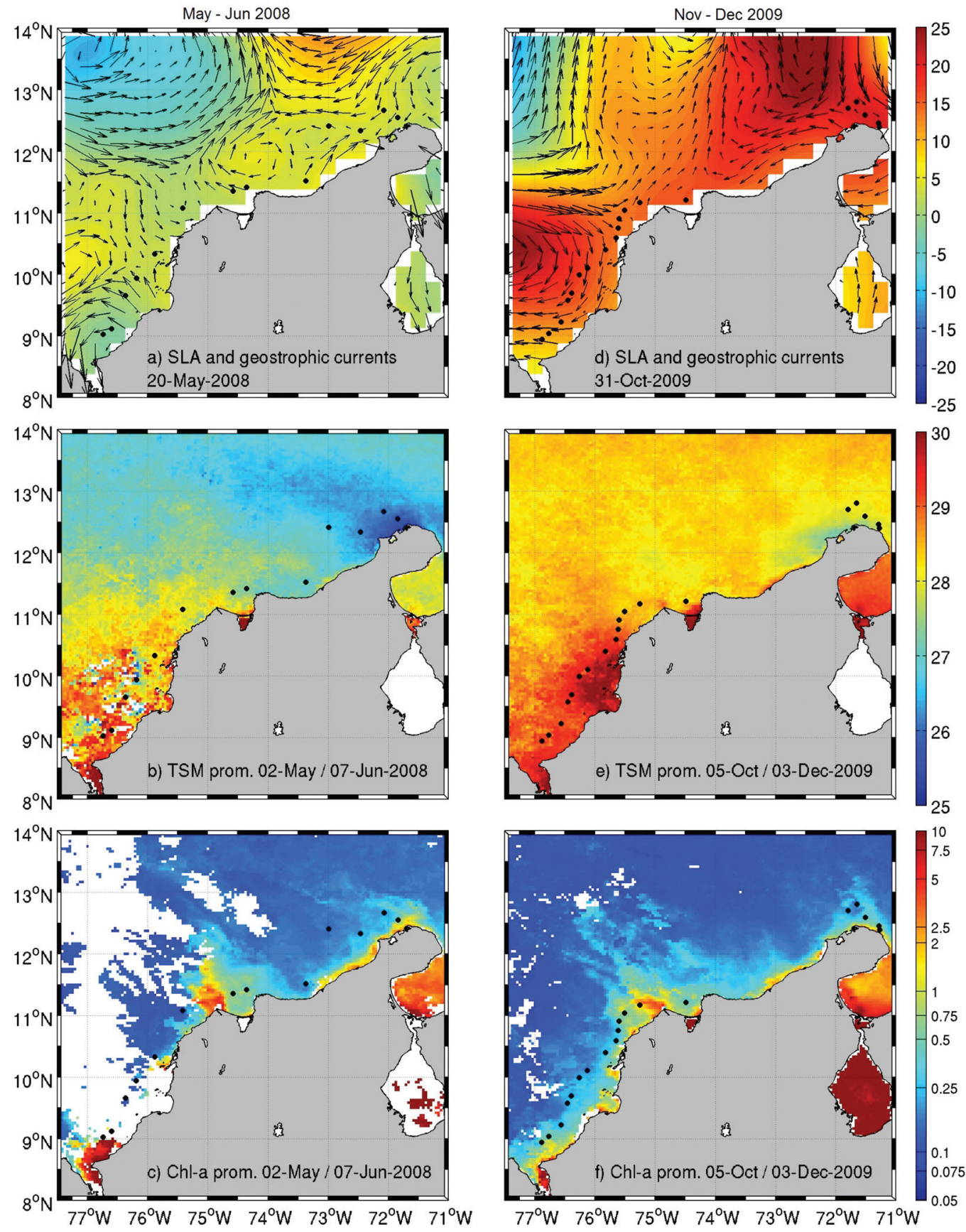

Fig. 2. Environmental conditions during the transitional (May-June 2008) (A,C,E) and rainy seasons (Nov-Dec 2009) (B,D,F). A-B. Sea Level Anomaly (cm) and Geostrophic current; C-D. Mean Sea Surface Temperature ${ }^{\circ} \mathrm{C}$; E-F. Mean Chla $\left(\mathrm{mg} \cdot \mathrm{m}^{-3}\right)$. 

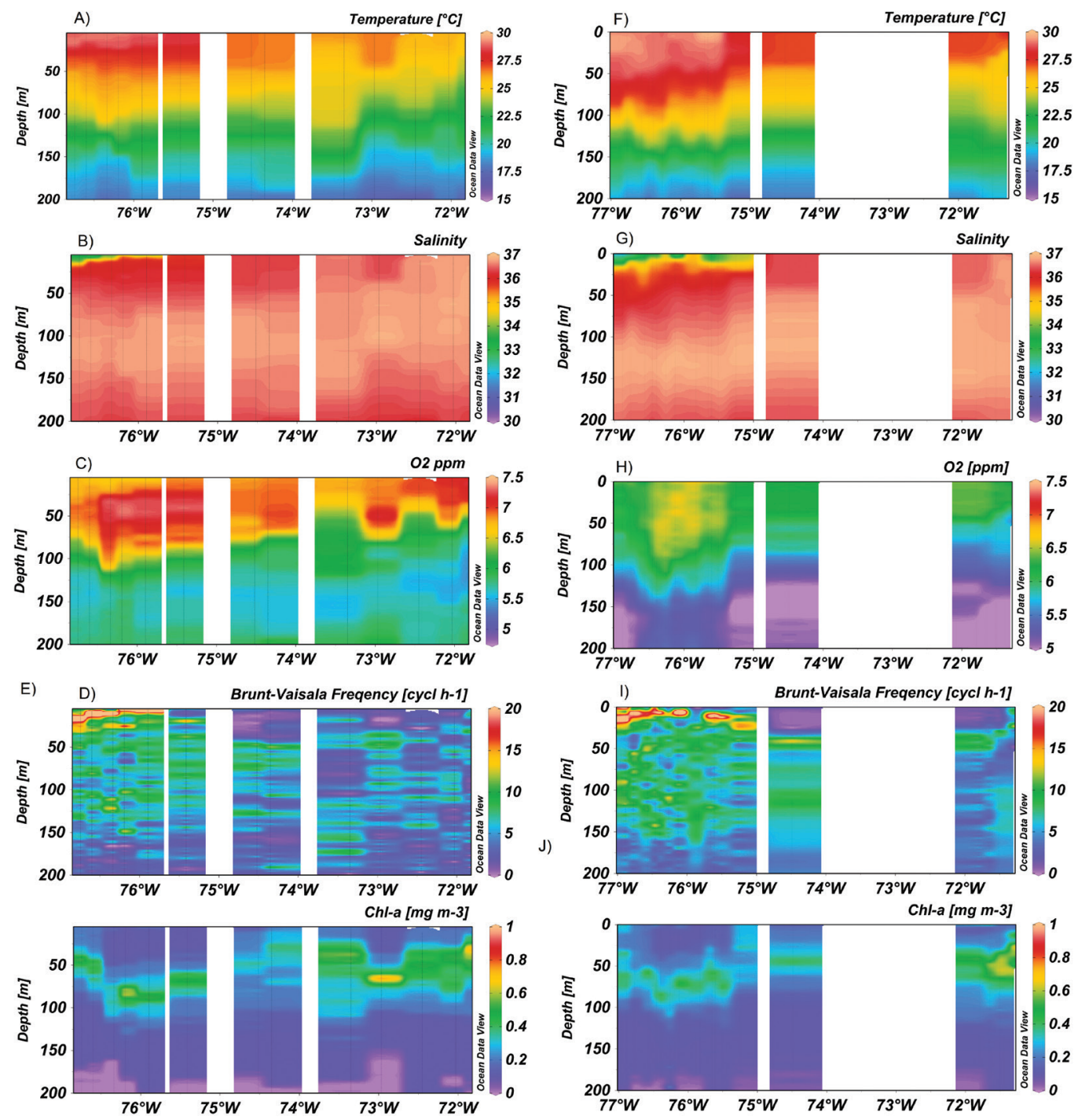

Fig. 3. Vertical section during the transitional (May-June of 2008) (A,C,E,G,I) and rainy seasons (Nov-Dec of 2009) (B, D, F, H, J). A-B. Temperature $\left({ }^{\circ} \mathrm{C}\right)$; C-D. Salinity; E-F. Oxygen (ppm); G-H. Brunt-Vaisala Frequency (cph); I-J. Chla $\left(\mathrm{mg} \cdot \mathrm{m}^{-3}\right)$.

$\mathrm{m}$, while below $150 \mathrm{~m}$ the temperature was $<$ $20{ }^{\circ} \mathrm{C}$ (Fig. 3A and Fig. 3F). The thermocline was shallower in the Northeastern than in the Southwestern zone in the transition 1 period (Fig. 3A), revealing the presence of upwelling in the former.

Salinity was homogeneous through most of the study, with the highest values (ca. 35) in the near surface layer $(0-15 \mathrm{~m})$, although the
Southwestern area had lower values (33-34) in near surface waters, possibly associated with river discharge. This pattern was more evident during the rainy season (Fig. 3B and Fig. 3G).

During both seasons, the concentration of oxygen was higher in the surface layer $(>6$ $\mathrm{ppm})$, and the water column of the Southwestern zone was more oxygenated, with higher values of oxygen $(7.5 \mathrm{ppm})$, and a deeper 
oxycline $(\sim 100 \mathrm{~m})$ than in the other zones (Fig. $3 \mathrm{C}$ and Fig. 3H). The shallower oxycline in the Northeastern area, observed in both seasons, was probably related to upwelling taking place in the zone.

In relation to the physical structure of the water column, we used Brunt-Vaisala frequency to assess stratification (Fig. 3D and Fig. 3I). In both transition seasons, there was a clear distinction between the Northeastern and Southwestern zones. The latter was more stratified, with the highest values $(15-20 \mathrm{cph}$ (cycle per hour)) between 0-30 $\mathrm{m}$ depth. The central zone exhibited a mixed condition in the upper layer (0-50 $\mathrm{m}$ ) and was more stratified in deeper water. The Northeastern zone showed a highly mixed water column, although with slight stratification in mid and deeper layers (Fig. 3D and Fig. 3I).

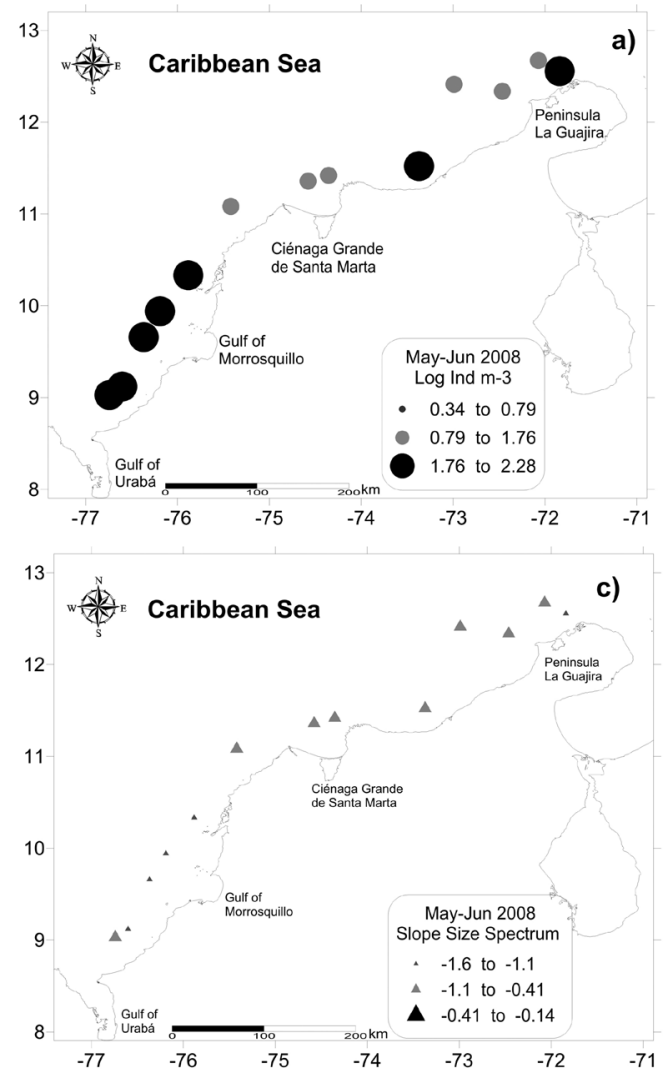

Chl $a$ levels and distribution were similar in the two transition seasons, although with strong spatial variation. The highest Chla concentration $\left(0.4-1 \mathrm{mg} \mathrm{m}^{-3}\right)$ in both seasons was found between 50 and $100 \mathrm{~m}$ in the Southwestern zone, while the maximums in the central and Northeastern zones were slightly shallower (Fig. 3E and Fig. 3J).

Zooplankton responses: There was relatively high abundance of zooplankton (13187 ind. $\mathrm{m}^{-3}$ ) in the transition 1 season in the Northeastern zone, with some isolated values in Southwestern areas, while there was less abundance in the central zone (Fig. 4A). Size spectrum slopes were steeper (more negative) for the Southwestern zone, indicating the prevalence of small organisms, whereas flatter size spectrum slopes were estimated for the

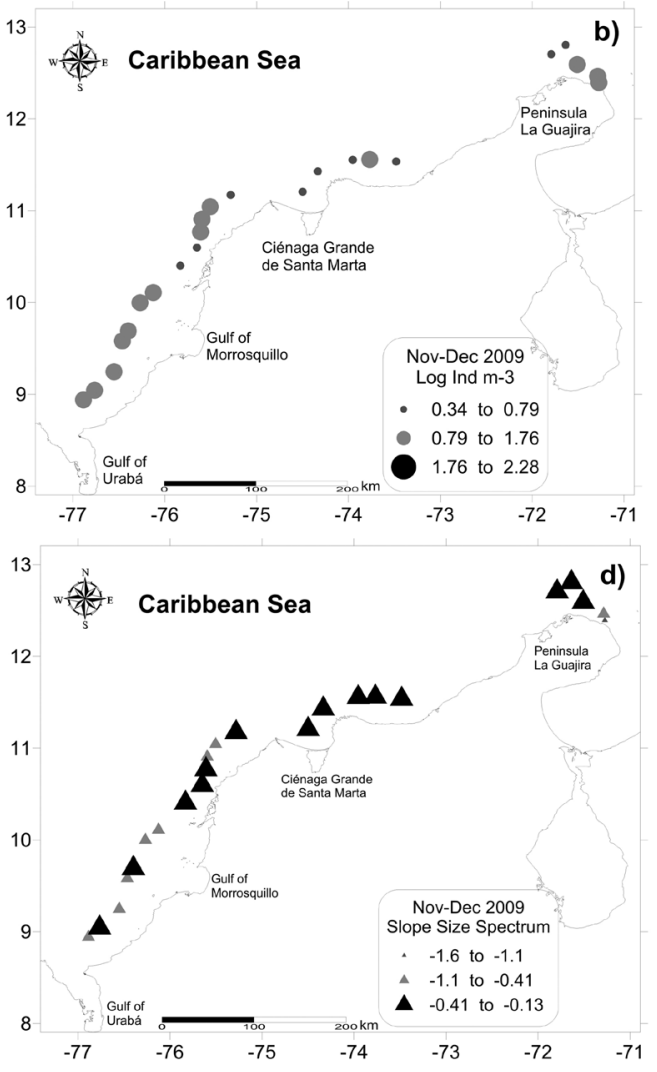

Fig. 4. Distribution of zooplankton abundance and the size spectrum slope for May-June 2008 (A, C) and Nov-Dec 2009 (B, D). 
central and Northeastern zones, indicating that size classes were more evenly distributed (Fig. 4C). A similar comparison was made between seasons. In this case, the size spectrum slopes were steeper transition1 season. This pattern was evident after considering the regressions between seasons (Digital Appendices). The diversity index, and the diversity size classes were higher in the Northeastern zone, and the lowest values were for the central zone (Fig. 5A and Fig. 5C).

During the transition 2 season the highest abundances of zooplankton occurred in the Southwestern zone, and in the most Northeastern station of the study area (Fig. 4B). The lowest abundance was in the central zone (Fig. 4B). The Southwestern zone showed more negative size spectrum slopes (dominance of small organisms), and slopes for the central and Northeastern zones were more positive (flatter) (Fig. 4D). The highest values of taxa diversity and size class diversity were for the central, and Southwest zones (Fig. 5B and Fig. 5D).

A two-way ANOVA, to test the differences in spatial distribution of zooplankton categorized by zone (Northeastern, central and Southwestern), showed significant differences only for zooplankton abundance. Seasonal effects (transition 1 vs. transition 2) were significant in zooplankton abundance, the size spectrum slope and the taxa diversity index, but not for size-class diversity index (Table 1).

Environmental and zooplankton correlations: Spatial (Northeastern, central and Southwestern zones), and temporal (transition
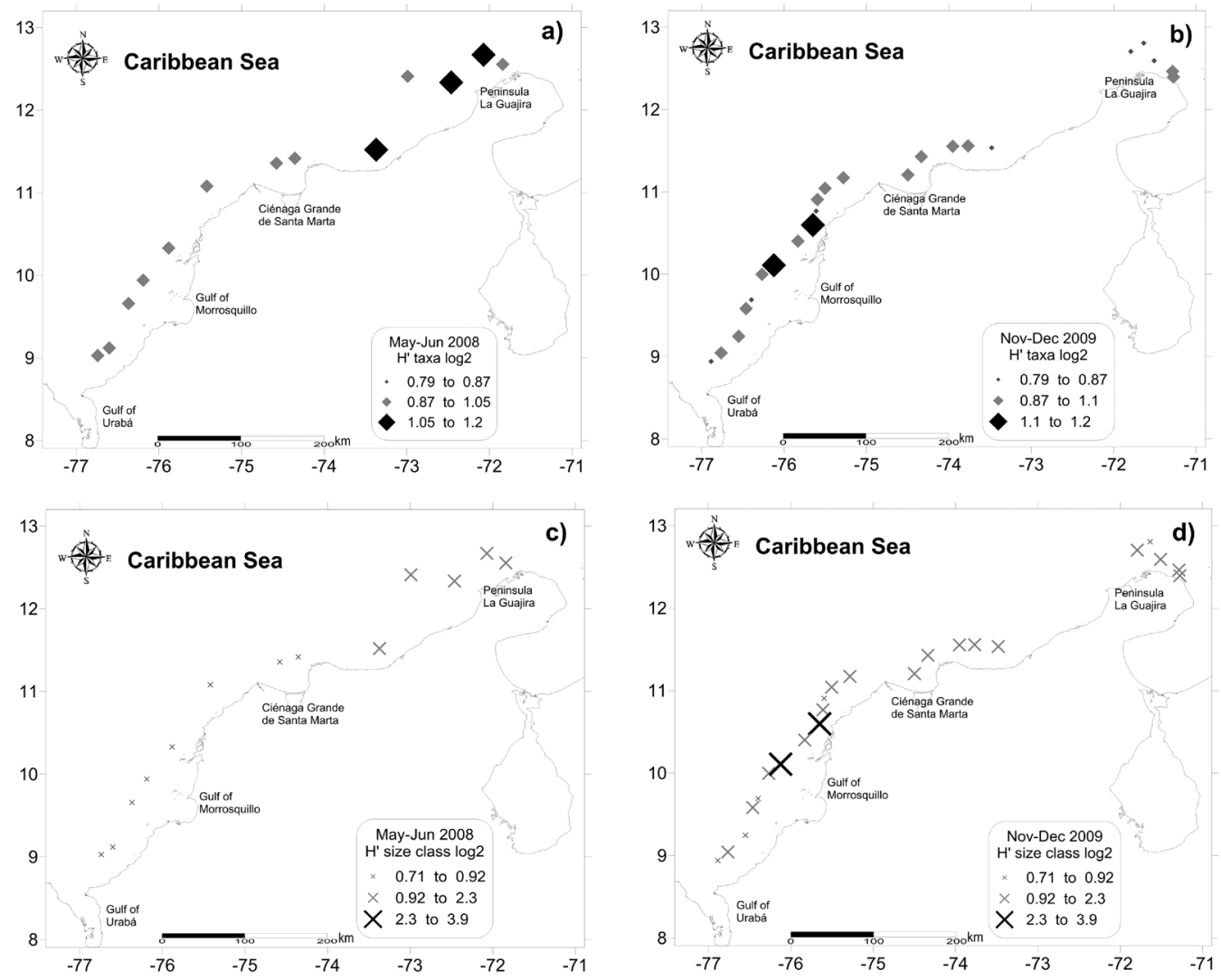

Fig. 5. Distribution of the Shannon-Wiener diversity index for taxa and size classes for May-June 2008 (A, C) and November-December 2009 (B, D). 
TABLE 1

Two-way ANOVA to test the effects of variable conditions in the Colombian Caribbean on abundance and the size spectra slope of the zooplankton community

\begin{tabular}{|c|c|c|c|c|c|}
\hline Source of variation & $\mathrm{df}$ & Sum Sq & Mean Sq & $\mathrm{F}$ ratio & P-Value \\
\hline \multicolumn{6}{|l|}{$\log N\left(\right.$ ind. $\left.m^{-3}\right)$} \\
\hline Zone & 2 & 1.227 & 0.613 & 5.737 & $0 * * *$ \\
\hline Season & 1 & 4.482 & 4.482 & 41.924 & $0.008 * * *$ \\
\hline Error & 30 & 3.207 & 0.107 & & \\
\hline \multicolumn{6}{|l|}{ Slope size spectrum (b) } \\
\hline Zone & 2 & 0.283 & 0.142 & 2.425 & 0.106 \\
\hline Season & 1 & 2.541 & 2.541 & 43.545 & $0 * * *$ \\
\hline Error & 30 & 1.751 & 0.058 & & \\
\hline \multicolumn{6}{|l|}{ Taxa index } \\
\hline Zone & 2 & 0.009 & 0.005 & 0.766 & 0.474 \\
\hline Season & 1 & 0.071 & 0.071 & 11.841 & $0.002 * *$ \\
\hline Error & 30 & 0.18 & 0.006 & & \\
\hline \multicolumn{6}{|l|}{ Size class index } \\
\hline Zone & 2 & 0.542 & 0.271 & 1.035 & 0.367 \\
\hline Season & 1 & 0.454 & 0.454 & 1.733 & 0.198 \\
\hline Error & 30 & 7.854 & 0.262 & & \\
\hline
\end{tabular}

*** Significant value to $0.05 \%$.

1 and transition 2) variability in environmental conditions were assessed through a Principal Component Analysis (PCA). A non-rotated PCA resulted in a first component (PC1) that explains $63.6 \%$ of total variance and a second component that explains $17.6 \%$. Temperature and density were associated with PC1, but with different signs, while oxygen in the mixed layer (ML) was positively related to PC2, and negatively to sea level anomaly (SLA) and Chla. Brunt-Vaisala Frequency and potential energy anomaly, MLD and salinity were associated with the two components, but made more contribution in PC1 (Fig. 6). Northeastern stations and some central zone stations were positively related to MLD, salinity, and density (Fig 6A). Most of the central and Southwestern stations were positively related to BFV, PEA and temperature. The transition 1 season (May-Jun 2008) had positive values in PC2 (Fig. 6B). Stratification parameters (BVF and PEA), and temperature were associated with a group of transition 2 season (Nov-Dec 2009) samples, and another group with density, MLD and salinity.
The zooplankton community structure also exhibited strong variation in terms of taxa composition. Copepods dominated the community in all situations ( $>70$ in relative abundance), although Salpidae and Chaetognatha were also abundant and persistent. Other taxa were also common, but in lower abundance (Fig. 7). For all taxonomic groups, much greater abundance was found in the transitional season (May-June) than in the rainy season (November-December). Abundance was lower in the central zone than in other two zones in both seasons (Fig. 7).

The classification and ordination analyses (clustering, MDS) using the Bray-Curtis index with zooplankton abundance data, revealed the existence of two groups with $60 \%$ similarity. A similarity analysis (ANOSIM) between seasons (May-Jun 2008 and Nov-Dec 2009) showed significant differences in zooplankton abundance and community composition $(\mathrm{R}=$ $0.359, \mathrm{P}<0.05)$, but not among zones $(\mathrm{R}=$ $0.031, \mathrm{P}>0.05)$. The multivariate analysis at the spatial scale showed a separation into two groups: in the first group were mainly central 

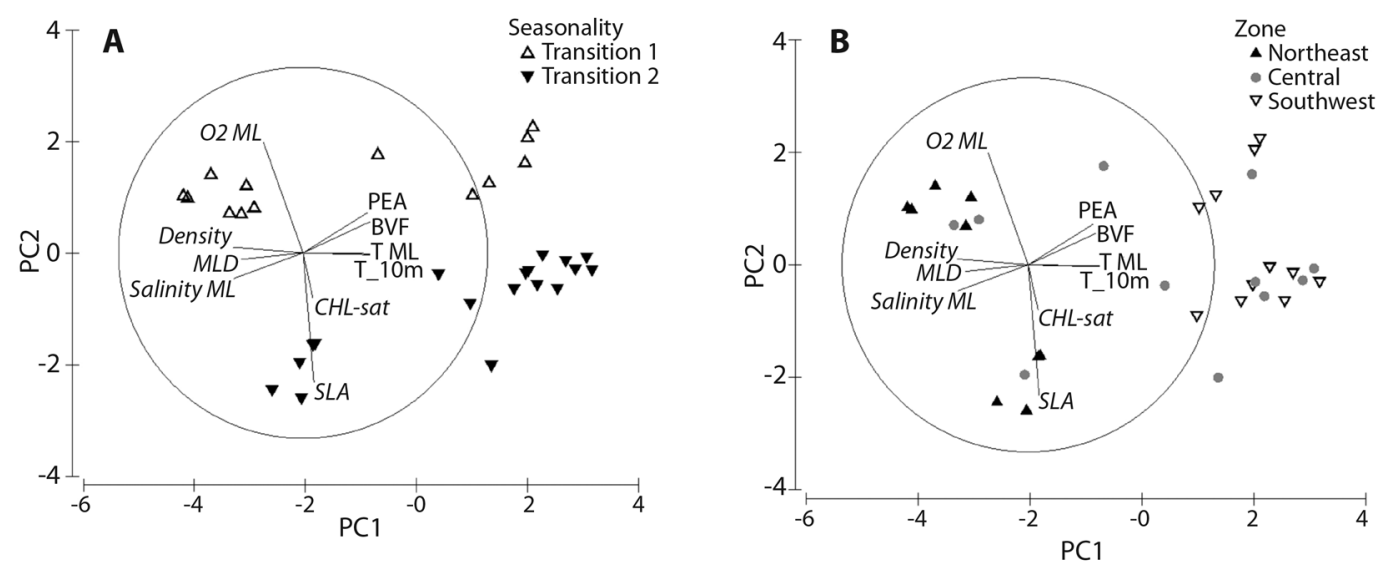

Fig. 6. A principal component analysis to assess oceanographic variability in the Colombian Caribbean for: A) spatial distribution in three zones: Northeastern, central and Southwestern and B). Two seasons: Transition1 (May-June 2008) and Transition 2 (November-December 2009). BVF= Brunt-Väisälä frequency, PEA=Potential Energy Anomaly, MLD= Mixed Layer Depth, $T_{-} M L=$ Mean temperature of Mixed Layer, $T_{-} 10 \mathrm{~m}=$ Temperature at 10 meters, $\mathrm{O}_{2} \mathrm{ML}=\mathrm{Mean}$ Oxygen concentration of Mixed Layer, Density=Sigma T (0-50 m), Chl $a=$ Chlorophyll $a$, SLA=Sea Level Anomaly.

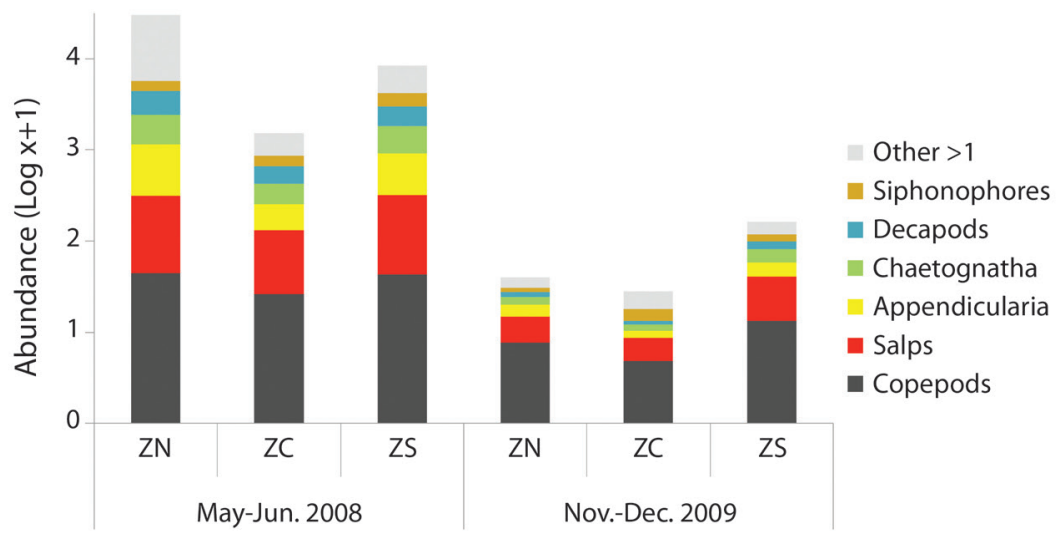

Fig. 7. Composition and abundance of the zooplankton community in the Colombian Caribbean in two seasons and three spatial zones. Abundance is expressed as individuals. $\mathrm{m}^{-3}$ (log.scale). ZN, ZC, ZS are the Northeastern, central and Southwestern zones, respectively.

zone stations, and the other, included stations from the three zones (Fig. 8A). According to the seasonal factor, stations of the transition 2 season (Nov-Dec 2009) were associated with the first group, and stations for the two transition seasons were associated with the second group (Fig. 8B). Within the second group, clustering of $80 \%$ similarity separates into two periods. SIMPER analysis by season revealed a mean similarity contribution of $76.05 \%$ to taxonomic composition of the transition1 season stations, characterized by high abundance of copepods and salps. The taxonomic similarity to the transition 2 season was 64.72 $\%$, and conversely to the transition 1 season, the same groups were found as high contributors to dissimilarity between seasons.

According to the BIOENV analysis, the main variables explaining the biological ordination were sea level anomaly and Chla concentration, which in combination, had a Spearman correlation of 0.49 (Table 2). Other 


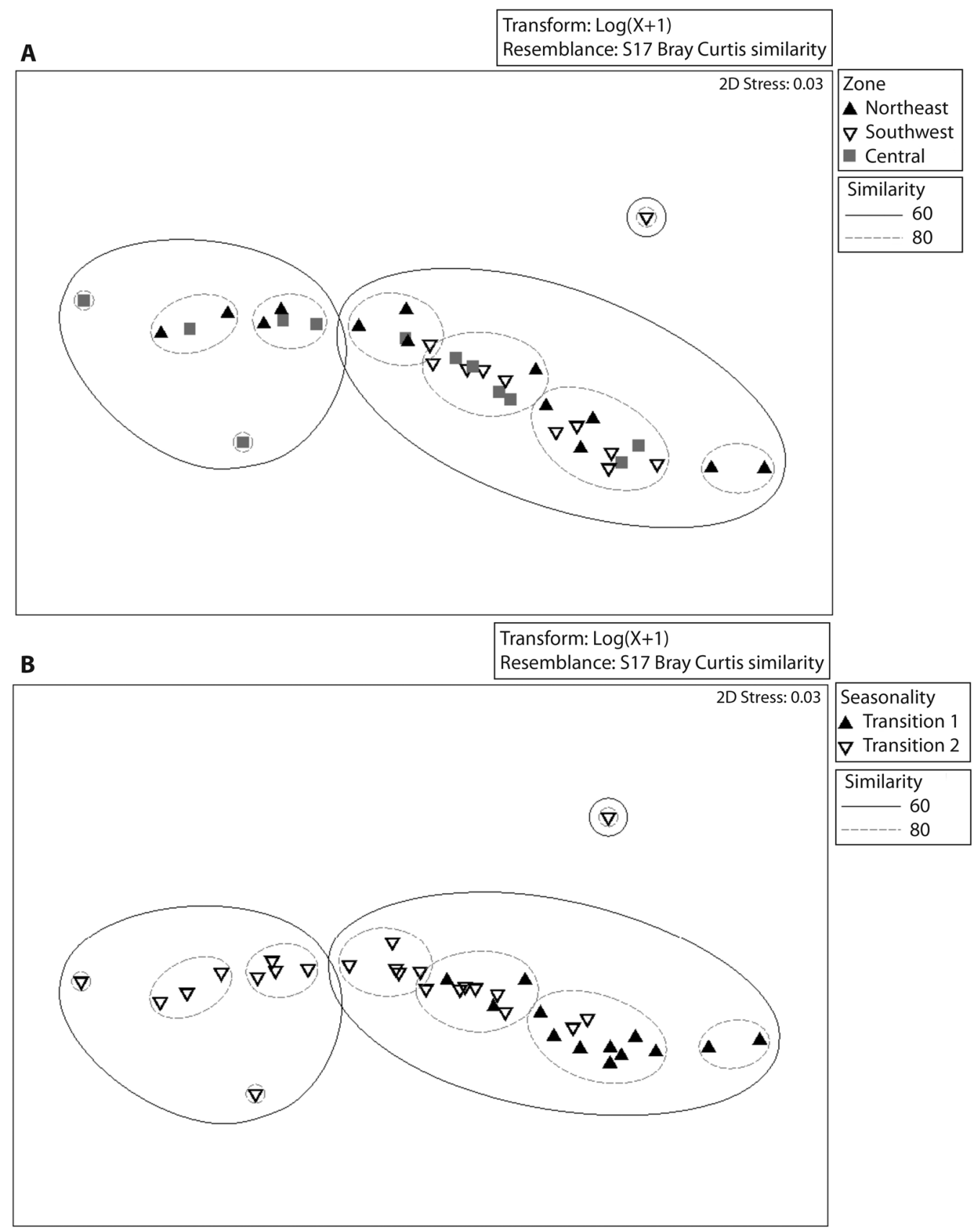

Fig. 8. Non-metric multidimensional scaling (NMDS) plot for the first two axes, based on Bray-Curtis similarities of the log $(\mathrm{x}+1)$ of transformed zooplankton abundance data for: $\mathrm{A})$ zones and $\mathrm{B}$ ) seasons (stress $=0.03)$. 
TABLE 2

Best combinations of oceanographic variables that influence the zooplankton community based on the bio-environmental analysis

\begin{tabular}{ccc} 
No. of variables & Best combinations & Spearman correlation \\
2 & Chla - SLA & 0.494 \\
3 & MLD - Chla - SLA & 0.447 \\
3 & O2 - Chla - SLA & 0.433 \\
4 & MLD - O2 - Chla - SLA & 0.414 \\
1 & SLA & 0.379 \\
3 & BVF - Chla - SLA & 0.375 \\
4 & BVF - O2 - Chla - SLA & 0.374 \\
5 & BVF - MLD - O2 - Chla - SLA & 0.347 \\
2 & O2 - SLA & 0.343 \\
4 & BVF - MLD- Chla - SLA & 0.310 \\
\hline
\end{tabular}

$\mathrm{BVF}=$ Brunt-Vaisala frequency, $\mathrm{MLD}=$ Mixed Layer Depth, O2_ML= Mean Oxygen concentration of Mixed Layer, Chla= Chlorophyll $a$, SLA=Sea Level Anomaly. Spearman correlation indicates the degree of co-variation between the biotic component and abiotic variables.

TABLE 3

Stepwise regression models for biological variables vs. environmental variables for the two transition seasons

\begin{tabular}{ccccc} 
& Slope & Taxa diversity & Size class index & Ln N \\
FBV $(\mathrm{cph})$ & $-0.006(0.004)$ & & & $0.014(0.000)$ \\
O2 MLD & $-0.535(0.014)$ & $0.182(0.005)$ & $0.863(0.093)$ & $0.892(0.004)$ \\
Chla (ug.m $\left.{ }^{-2}\right)$ & $4.807(0.000)$ & & $6.771(0.003)$ & $-4.390(0.001)$ \\
Constant & 2.799 & -0.246 & -5.050 & -4.892 \\
F & 23.609 & 9.334 & 5.185 & 21.866 \\
P & 0.000 & 0.005 & 0.012 & 0.000 \\
Adj R & 0.693 & 0.217 & 0.218 & 0.676 \\
\hline
\end{tabular}

Each column gives coefficients for significant predictors based on the final stepwise regression model for the variables listed in the first row (P values in parentheses). The last three rows are the values of $\mathrm{F}$ test, and $\mathrm{R}^{2}$.

variables selected in combinations with Spearman coefficients $<0.3$ are shown in Table 2 . A stepwise multiple regression selected BruntVaisala frequency, oxygen and Chl $a$ as the most important predictors for abundance and the size spectrum slope. The best predictor for the taxa diversity index is oxygen concentration, and the best predictors for size-class diversity are oxygen and Chla (Table 3 ).

In this study 53 copepod species (listed in Supplemental Material) were identified at five stations from the transition 1 season. The most representative species with $>1 \%$ relative abundance were presented in figure 9. Paracalanus parvus, Temora turbinata, Oithona plumifera, Subeucalanus subtenuis, Clausocalanus arcuicornis and Oncaea venusta were the most abundant (>3.5\%). Some changes were evident in terms of relative abundance. For example, T. turbinata and S.s subtenuis were common in the Northeastern zone, C. arcuicornis in the central zone and $P$. parvus and $O$. plumifera in the Southwestern zone. Differences and similarities in species composition among zones are illustrated in figure 9.

\section{DISCUSSION}

During 2008 and 2009 the mean rainfall was much lower than would be expected for a 


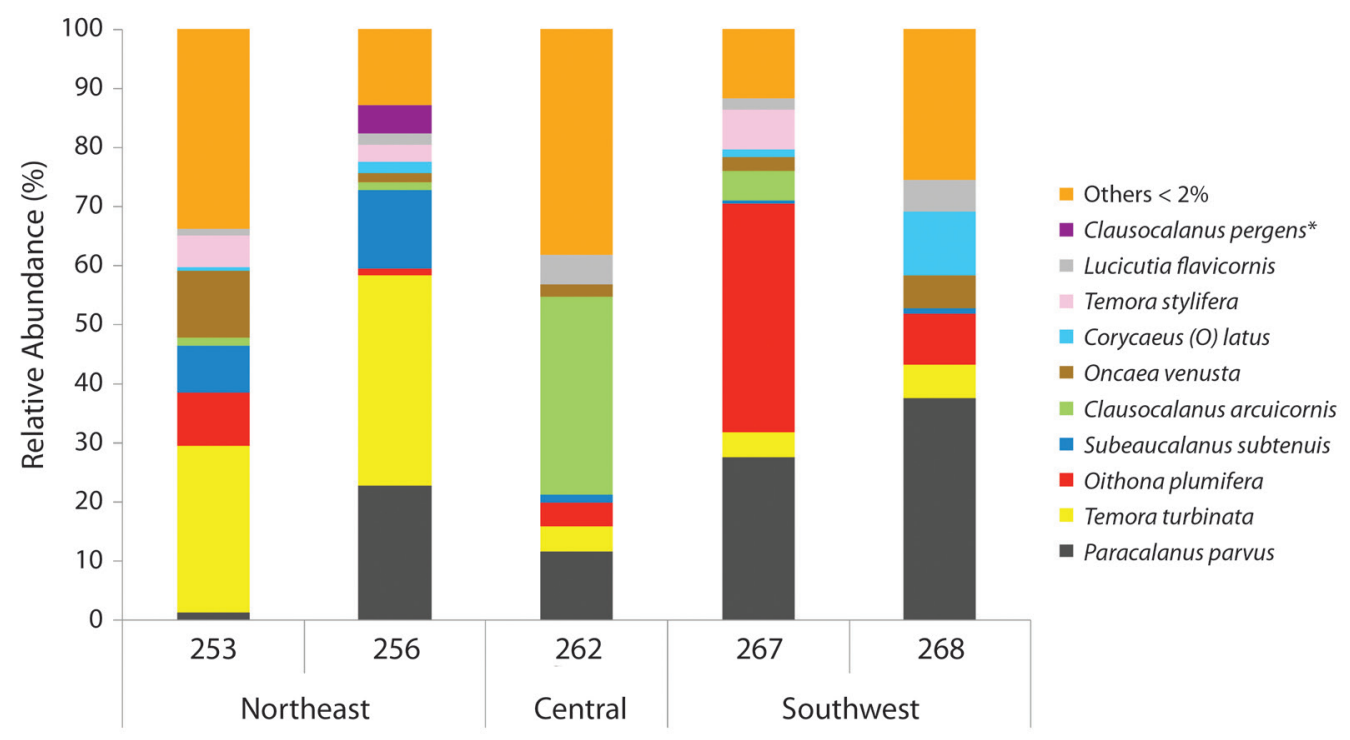

Fig. 9. Relative abundance of copepod species to illustrate changes in the most abundant copepod species in May-June 2008 at selected stations (Fig. 1).

region considered a tropical system, with a North-South gradient in the range of 250-1250 mm a year (Arango, Dorado, Guzmán, \& Ruíz, 2014). In the study area, no differences were found in the precipitation during transition periods, the variations were evident at spatial level among the sectors analyzed. Low rainfall probably reflected the impact of climate change on this zone. In fact, Taylor et al. (2012) in the Southern zone of the Caribbean (CariacoVenezuela) from 1996 to 2010, recorded an increase in surface temperature, and stratification and a decrease in upwelling, chlorophyll and primary production, as well as changes in the plankton structure. The weakening trend in Trade Winds and dependent local variables are largely explained by altering the Intertropical Convergence Zone (ITCZ) and North Atlantic oscillation (NAO).

Temporal and spatial changes in oceanographic variables, such as temperature, oxygen, chl $a$ and sea level anomaly (mesoscale) were evident. Strong mesoscale activity in the form of cyclonic and anticyclonic eddies was observed during our cruises in the Colombian Caribbean, with maximal activity in May and June 2008. The dynamics of these gyres seems related to displacements of the Intertropical Convergence Zone (ITCZ) through its influence on variability of wind circulation patterns (Low Level Atmospheric Jet), and the salinity gradients generated in the Southwestern zone (Andrade \& Barton, 2000). In the Northeast zone, eddies are formed and transported in both seasons in the Caribbean current that enters the Colombia basin from Brazil. The Caribbean current has a constant flow towards the Western zone and carries mesoscale eddies with sizes between $100-500 \mathrm{~km}$ at a speed of about $30 \mathrm{~cm} . \mathrm{s}^{-1}$ (Kinder, Heburn, \& Green, 1985; Nystuen \& Andrade, 1993; Fratantoni, Johns, \& Townsend, 1995; Andrade \& Barton, 2000). In the central zone during May-June 2008 cyclonic and anticyclonic eddies were present. During November-December 2009, no mesoscale activity was observed, a front area between two large anticyclonic turns was observed. Depending on seasonality, areas of fronts or instabilities may occur in the central zone, due to the encounter of the Caribbean Current to the Southwest with the Darien Countercurrent in the Northwest direction, and the continental discharges of the Magdalena River and the Dique channel. In the Southwestern area, eddies recorded in both 
seasons are advected from the permanent and large-scale cyclonic circulation of the PanamaColombia gyre, as described by several authors (Mooers \& Maul, 1998; Andrade \& Barton, 2000; Jouanno, Sheinbaum, Barnier, Molines, Debreu, \& Lemarié, 2008).

Upwelling conditions were evident during the first period of transition, temperature was lowest and thermocline was more superficial in the Northeast than in the Southwest zone, higher mixing was observed in this zone. In the Colombian Caribbean, the upwelling intensifies in the period of strong winds, but can occur in other seasons of the year (Andrade \& Barton, 2005). In contrast, in the Southwestern zone, during the two study periods, water of higher temperature, lower salinity and greater stratification was found; this zone presented a narrow continental shelf and greater depth (Restrepo, 2008; Rangel-Buitrago \& IdárragaGarcía, 2010). In addition, it is influenced by discharges of fresh water and sediments from the Magdalena River, Canal del Dique, Sinú river and Atrato river entering the Colombian Caribbean (Restrepo, Zapata, Díaz, GarzónFerreira, \& García, 2006). The warming of the Southwest zone may be related to the persistence of the cyclonic circulation of Southwest zone, orientation of the coastline that protects it from the winds and the influence of the discharges of the rivers and the cooling of the Northeastern zone with the orientation of the coastline and the upwelling (Bernal, Poveda, Roldán, \& Andrade, 2006).

We found that differences in temporal distribution of taxa and size of zooplankton were determined by mesoscale variability, dominant circulation and local conditions (e.g. upwelling). Zooplankton was more abundant in the first period of transition, which may be due to greater enrichment by upwelling in the Northeastern zone, along with transport to the West by the Caribbean current associated with greater mesoscale activity (eddies). Zooplankton abundance in the Northeastern zone was related to more positive size spectrum slopes, as well as higher in taxa and size diversity indexes. Nutrient input by upwelling in the Northeastern zone sustained new production and provided more food for zooplankton, which may explain greater zooplankton abundance. Upwelling can also cause vertical ascent of species from deep water, which may increase taxa diversity. These species can then be advected to oceanic areas by mesoscale eddies. In May-June 2008, a cyclonic eddy was present in Northeastern Colombia (the border with Venezuela), and an anticyclonic eddy in the central zone. Our sampling stations were located in the area of interaction between the eddies, both of which transported nutrient-rich coastal waters to the more oceanic zone. Eddies can transport the complete plankton community, as has been seen in other regions (Morales et al., 2010), even for months (Chenillat et al., 2015) and such process can be enhanced by the interaction between cyclonic and anticyclonic eddies (Moore, Matear, Marra, \& Clementson, 2007).

The central zone of our study is directly subjected to discharges from the Magdalena River (Bocas de Ceniza) and the Canal del Dique. Zooplankton abundance was high in the Northeastern zone in both seasons, with highly variable size spectrum slopes, although they were generally positive (steeper). The diversity indexes were low in May-June 2008 and higher in November-December 2008. The relatively high variation may result from a frontal area originating from the Caribbean current and the Panamá-Colombia countercurrent. Taking mesoscale eddies into consideration, this area behaves like a frontal zone between eddies, which according to their circulation, cyclonic or anticyclonic, export or import zooplankton diversity from or to the region. Increased Chla off the mouth of Magdalena River, as evidenced by the satellite image map showing an offshore extension in May-June 2008, reveals advection to the oceanic area. In contrast, this Chla plume is slightly displaced to the Southwest in October-November 2009. These frontal zones aggregate higher levels of biological activity with greater concentrations of phytoplankton and zooplankton, along with increased yields of fish (Mann \& Lazier, 1991). 
Finally, zooplankton abundance was high in the Southwestern region, but the size spectrum slopes were extremely negative (dominance of small organisms) and both indexes of diversity (taxa and size) were lower than in the other regions. This region was characterized by high temperature and stratification in both seasons, possibly linked to transport, cyclonic circulation (Panama-Colombia Gyre) and recirculation of low salinity fresh water from the Magdalena, Sinú and Atrato Rivers. In this context, Restrepo et al. (2014) described a 65 $\%$ increase in river outflow into the Caribbean for the period 2000-2010, reflecting the drift of the ITCZ and suggesting that such climatic processes are key factors in causing observed oceanographic variability.

The observed patterns of zooplankton size distribution for the two seasons and three zones, as assessed by the size spectrum slope and our size/taxa indexes, may be modulated by transport, mixing and dispersion under variable circulation regimes. However, these patterns ultimately follow changes in taxa composition in terms of species or other taxonomic categories. ZooImage classification showed significant changes in community composition between seasons. Although copepods dominated the community in both periods, salps, siphonophores, chaetognaths and decapods, were more abundant during the first period, and because they are larger in size, probably contributed to the observed changes in size structure. However, changes in taxa composition among zones were unclear and non-significant according to ANOSIM, which is consistent with the absence of significant differences in the size spectrum slope among zones.

Nevertheless, a closer look at the community structure at the species level, as we did with copepods, showed that there was variation among zones, which affects community structure. Our copepod species analysis revealed substantial variation in species among zones. In this regard, warm (more stratification) or cold (upwelling) conditions may favor the prevalence of certain species compared to neighboring zones, as observed in other regions (Hidalgo, Escribano, Vergara, Jorquera, Donoso, \& Mendoza, 2010). Food aggregation also promotes species distribution and abundance (Irigoien et al., 2009). The effect of biological processes like predation on distribution patterns should also be considered (Verheye, Hutchings, Huggett, \& Painting, 1992). The presence of other copepod predators, such as siphonophores and chaetognaths, especially during May-Jun 2008, possibly affects copepod abundance and structure. Nevertheless, because most observed variability is associated with size structure and distribution, it is reasonable to infer that physical processes are mainly responsible for observed patterns. There is much evidence that the responses of zooplankton to advection and mixing are size-dependent (Peterson, 1998; Hidalgo, Escribano, Jorquera, \& Vergara, 2012).

To summarize, our analyses evidenced changes in the spatial size-taxa structure of the zooplankton community for both seasonal periods. These changes are related to: 1) Moderate upwelling, with more mixing, a deeper mixed layer and lower temperatures in May-June 2008, resulting in greater abundance of zooplankton and greater diversity indexes, especially in the Northeastern and central zone, 2) Variability in mesoscale activity between seasons, which for the Colombian Caribbean may control spatial distribution of zooplankton. Mesoscale activity transports or disperses nutrients, plankton, diversity between the coastal and oceanic zones, and thus affects the spatial structure of zooplankton. Cyclonic and anticyclonic eddies clearly explain zooplankton distribution patterns and this is reinforced by our multiple regression analysis, which shows that stratification, dissolved oxygen and Chl $a$ are the best predictors of zooplankton abundance, size spectrum slopes and diversity indexes. Moreover, sea level anomaly (mesoescale) and Chla were best combination of variables that explain the abundance and distribution of zooplankton. 


\section{ACKNOWLEDGMENTS}

This work was funded by FONDECYT Chile, Grant 1120478 and the Instituto Milenio de Oceanografía (IMO). Graduate studies of J. Medellín-Mora were supported by a CONICYT Chile Scholarship and a REDOC project of the Universidad de Concepción. We thank The National Agency Of Hydrocarbons of Colombia, the Institute of Marine and Coastal Research - INVEMAR, the Marine Ecosystem Biodiversity Program (BEM) and the Natural Marine History Museum of Colombia (MHNMC), the B/I ANCON crew and scientific staff who participated in the cruises. We also thank the Colombian Instituto de Hidrología, Meteorología y Estudios Ambientales - IDEAM for providing rainfall data.

\section{RESUMEN}

Variabilidad espacial de la estructura comunitaria del zooplancton en aguas oceánicas del Caribe colombiano durante dos estaciones. El zooplancton es un componente importante para entender la dinámica oceanográfica, es considerado un buen indicador de la variabilidad ambiental, ya que la mayoría de las especies tienen ciclos de vida cortos, por lo que puede haber un estrecho acoplamiento entre el clima y la dinámica de la población, algunos grupos son sensibles a variables como la temperatura, calidad y cantidad de alimento, oxigenación y estratificación. En el Caribe colombiano dos cruceros oceanográficos durante Mayo-Junio 2008 y Noviembre-Diciembre 2009 fueron realizados con el fin de caracterizar y analizar la biodiversidad del margen continental del Caribe colombiano. El objetivo de este estudio fue determinar qué variable oceanográfica es la más importante en la distribución del zooplancton en las aguas oceánicas del Caribe colombiano $\mathrm{y}$ de qué forma estas variables estructuran la comunidad. En cada crucero se obtuvieron muestras de zooplancton mediante arrastres verticales con una red cónica de $1 \mathrm{~m}$ de diámetro de boca y $200 \mu \mathrm{m}$ de ojo de malla. La estructura comunitaria del zooplancton se estudió mediante el análisis automatizado de imágenes (ZooImage) el que combinado con datos de abundancia permitió calcular la pendiente del espectro de tamaño de la comunidad e índices de diversidad de taxa y tamaños. Las variables ambientales (temperatura, salinidad, oxígeno y clorofila a de la columna de agua) se obtuvieron desde los mismos cruceros y se utilizaron para calcular la estratificación mediante la frecuencia Brunt-Vaisala. Esta información in situ se complementó con imágenes satelitales de temperatura, clorofila superficial, corrientes geostróficas y nivel del mar, obtenidas de los productos MODIS y AQUA. La asociación entre variables ambientales y la estructura comunitaria del zooplancton se determinó mediante rangos de correlación de Spearman con la rutina Bioenv y un modelo de regresión paso a paso. El análisis de componentes principales (PCA) permitió observar patrones espaciales y temporales en las condiciones oceanográficas del área de estudio, tales como surgencia en la región Nororiental, fuerte estratificación en la Suroccidental y actividad de remolinos de mesoescala. La abundancia del zooplancton mostró diferencias entre las dos estaciones climáticas y entre las zonas. Diferencias temporales también fueron evidentes en el tamaño y diversidad de taxa (ANOVA 2-vías $\mathrm{P}<0.05$ ). Estos cambios se relacionaron con la surgencia moderada y la actividad de los remolinos de mesoescala. Los remolinos ciclónicos y anticiclónicos de tamaño variable pueden transportar o retener el zooplancton sobre áreas cruzadas y oceánicas, modificando así la estructura taxonómica de la comunidad. Según el análisis Bioenv las principales variables que explicaron la abundancia y composición del zooplancton fueron el nivel del mar y la clorofila a (correlación de Spearman $=0.49$ ). El modelo de regresión paso a paso mostró que la estratificación, el oxígeno y la clorofila a son los predictores mas importantes para la abundancia y el tamaño del zooplancton.

Palabras clave: mesozooplancton; espectro de tamaño; mesoescala; estratificación; distribución.

\section{REFERENCES}

Andrade, C. A., \& Barton, E. D. (2000). Eddy development and motion in the Caribbean Sea. Journal of Geophysical Research: Oceans, 105(C11), 26191-26201. DOI: $10.1029 / 2000 J C 000300$

Andrade, C. A., \& Barton, E. D. (2005). The Guajira upwelling system. Continental Shelf Research, 25(9), 1003-1022. DOI:10.1016/j.csr.2004.12.012

Andrade, C. A., Barton, E. D., \& Mooers, C. N. (2003). Evidence for an eastward flow along the Central and South American Caribbean Coast. Journal of Geophysical Research, 108(C6)3185, 1-16. DOI: 10.1029/2002JC001549

Andrade-Amaya, C. A. (2001). Las corrientes superficiales en la cuenca de Colombia observadas con boyas de deriva. Revista de la Academia Colombiana de Ciencias Exactas, Físicas y Naturales, 25(96), 321-335. (Recovered from http://www.accefyn.org.co/revista/ vol_25.htm)

Arango, C., Dorado, J., Guzmán, D., \& Ruíz, J. (2014). Informe análisis compuesto según el índice ENSO ONI, para la temperatura media trimestral de Colombia. IDEAM. Recuperado de http://institucional. ideam. gov. co/jsp/2456 (con acceso 20/10/2014). 
Beaugrand, G., Reid, P. C., Ibanez, F., Lindley, J. A., \& Edwards, M. (2002). Reorganization of North Atlantic marine copepod biodiversity and climate. Science, 296(5573), 1692-1694. DOI: $10.1126 /$ science. 1071329

Bernal, G., Poveda, G., Roldán, P., \& Andrade, C. (2006). Patrones de variabilidad de las temperaturas superficiales del mar en la costa Caribe colombiana. Revista de la Academia Colombiana de Ciencias Exactas, Físicas y Naturales, 30(115), 195-208 (Recovered from http://www.accefyn.org.co/revista/vol_30.htm).

Canales, T. M., Law, R., \& Blanchard, J. L. (2016). Shi$\mathrm{fts}$ in plankton size spectra modulate growth and coexistence of anchovy and sardine in upwelling systems. Canadian Journal of Fisheries and Aquatic Sciences, 73(4), 611-621. https://doi.org/10.1139/ cjfas-2015-0181

Chenillat, F., Franks, P., Riviére, P., Capet, X., Grima, N., \& Blanke, B. (2015). Plankton dynamics in a cyclonic eddy in the Southern California Current System. Journal of Geophysical Research: Oceans, 120(8), 5566-5588.

Clarke, K. R., \& Gorley, R. N. (2006). PRIMER v6: User Manual/Tutorial. England: Plymouth.

Clarke, K., \& Warwick, R. (2001). Change in Marine Communities: An approach to statistical analysis and interpretation, 2nd ed. England: Plymouth.

Correa-Ramírez, M. A., Hormazábal, S., \& Yuras, G. (2007). Mesoscale eddies and high chlorophyll concentrations off central Chile (29-39 S). Geophysical Research Letters, 34, L12604. DOI: 10.1029/2007GL029541

Di Mauro, R., Cepeda, G., Capitanio, F., \& M.D. Viñas. (2011). Using ZooImage automated system for the estimation of biovolume of copepods from the northern Argentine Sea. Journal of Sea Research, 66, 69-75. DOI:10.1016/j.seares.2011.04.013dx.doi. org/10.1038/189732a0

Escribano, R., Bustos-Ríos, E., Hidalgo, P., \& Morales, C.E. (2016). Non-limiting food conditions for growth and production of the copepod community in a highly productive upwelling zone. Continental Shelf Research, 126, 1-14. DOI: 10.1016/j.csr.2016.07.018

Franco-Herrera, A., Castro, L., \& P. Tigreros. (2006): Plankton Dynamics in the South-Central Caribbean Sea: Strong Seasonal Changes in a Coastal Tropical System. Caribbean Journal of Science, 42(1), 24-38. (Recovered from http://www.bioone.org/loi/cjos)

Fratantoni, D. M., Johns, W. E., \& Townsend, T. L. (1995). Rings of the North Brazil Current: Their structure and behavior inferred from observations and a numerical simulation. Journal of Geophysical Research: Oceans, 100(C6), 10633-10654. DOI: 10.1029/95JC00925
Gómez-Canchong, P. (2011). Estabilidad y resiliencia en comunidades marinas un enfoque alométrico (Doctoral dissertation, Universidad de Concepción. Facultad de Ciencias Naturales y Oceanográficas. Departamento de Oceanografía, Chile). Retrieved from Repositorio Udec (URI: http://repositorio.udec. cl/handle/11594/745)

Grosjean, P., \& Denis, K. (2007). ZooImage users manual. Retrieved from http://www.sciviews.org/zooimage/ docs/ZooPhytoImageManual.pdf

Gutiérrez, J. M. (2011). Estructura vertical del zooplancton oceánico del mar Caribe colombiano (Master's thesis, Universidad Nacional de Colombia, Santa Marta, Colombia). Available from bdigital repositiorio institucional UN (http://www.bdigital.unal.edu. co/7184/1/190253.2011.pdf)

Hays, G. C., Richardson, A. J., \& Robinson, C. (2005). Climate change and marine plankton, Trends in Ecology \& Evolution, 20(6), 337-344. DOI:10.1016/j. tree.2005.03.004

Hidalgo, P., Escribano, R., Jorquera, E., \& Vergara, O. (2012). How coastal upwelling influences spatial pattern of size-structured diversity of copepods in central southern Chile (summer 2009). Progress in Oceanography, 92-95,134-145. DOI: 10.1016/j. pocean.2011.07.012

Hidalgo, P., Escribano, R., Vergara, O., Jorquera, E., Donoso, K., \& Mendoza, P., 2010. Patterns of copepod diversity in the Chilean coastal upwelling system. Deep Sea Research Part II: Tropical Studies in Oceanography, 57, 2089-2097. DOI: 10.1016/j. dsr2.2010.09.012

IOC, SCOR, \& IAPSO. (2010). The International Thermodynamic Equation of Seawater - 2010: Calculation and Use of Thermodynamic Properties. Intergovernmental Oceanographic Commission, Manuals and Guides No. 56, UNESCO (English).

Irigoien, X., Fernandes, J. A., Grosjean, P., Denis, K., Albaina, A., \& Santos, M. (2009). Spring zooplankton distribution in the Bay of Biscay from 1998 to 2006 in relation with anchovy recruitment. Journal of Plankton Research, 31(1), 1-17. DOI: 10.1093/ plankt/fbn096

Jouanno, J., J., Sheinbaum, B., Barnier, J. M., Molines, J. M., \& Candela, J. 2012. Seasonal and Interannual Modulation of the Eddy Kinetic Energy in the Caribbean Sea. Journal of Physical Oceanography, 42, 2041-2055. DOI: 10.1175/JPO-D-12-048.1

Jouanno, J., Sheinbaum, J., Barnier, B., Molines, J.-M., Debreu, L., \& Lemarié, F. (2008). The mesoscale variability in the Caribbean Sea. Part I: Simulations and characteristics with an embedded model. Ocean Modelling, 23(3-4), 82-101. DOI: 10.1016/j. ocemod.2008.04.002 
Kinder, T. H., Heburn, G. W., \& Green, A. W. (1985). Some aspects of the Caribbean circulation, Marine Geology, 68(1), 25-52. DOI: 10.1016/0025-3227(85)90004-0

Krivtsov, V., Howarth, M., \& Jones, S. (2009). Characterising observed patterns of suspended particulate matter and relationships with oceanographic and meteorological variables: Studies in Liverpool Bay. Environmental Modelling \& Software, 24(6), $677-$ 685. DOI: 10.1016/j.envsoft.2008.09.012 - Source: DBLP

Lefort, S., Aumont, O., Bopp, L., Arsouze, T., Gehlen, M., \& Maury O. (2015). Spatial and body-size dependent response of marine pelagic communities to projected global climate change. Global Change Biology, 21(1), 154-164. DOI: $10.1111 / \mathrm{gcb} .12679$

Llinás, L., Pickart, R. S., Mathis, J. T., \& Smith, S. L. (2009). Zooplankton inside an Arctic Ocean coldcore eddy: Probable origin and fate. Deep Sea Research Part II: Topical Studies in Oceanography, 56(17), 1290-1304. https://doi.org/10.1016/j. dsr2.2008.10.020

López-Salgado, I., Gasca, R., \& Suárez-Morales. (2000). La comunidad de copépodos (Crustacea) en los giros a mesoescala en el occidente del Golfo de México (julio, 1995). Revista de Biologia Tropical, 48(1), 169-179. (Recovered from http://www.ots.ac.cr/rbt/ pages/vols/vol48-1.html).

Mann, K., \& Lazier, J. (1991). Dynamics of Marine Ecosystems. Biological-physical Interactions in the Oceans. Blackwell: Oxford, England.

Manríquez, K., Escribano, R., \& Riquelme-Bugueño, R. (2012). Spatial structure of the zooplankton community in the coastal upwelling system off central-southern Chile in spring 2004 as assessed by automated image analysis, Progress in Oceanography, 92-95, 121-133. DOI: $10.1016 /$ j.pocean.2011.07.020

Manríquez, K., Escribano, R., \& Hidalgo, P. (2009). The influence of coastal upwelling on the mesozooplankton community structure in the coastal zone off Central/Southern Chile as assessed by automated image analysis. Journal of Plankton Research, 31(9), $1075-1088$.

Medellín-Mora, J., \& Escribano, R. (2013). Análisis automático de zooplancton utilizando imágenes digitalizadas: estado del conocimiento y perspectivas en Latinoamérica. Latin American Journal of Aquatic Research, 41(1), 29-41. http://dx.doi.org/103856/ vol41-issue1-fulltext-2

Medellín-Mora, J., \& Martínez-Ramírez, O. (2010). Distribución del mesozooplancton en aguas oceánicas del mar Caribe colombiano durante mayo y junio de 2008. In INVEMAR (Eds.), Biodiversidad del Margen Continental del Caribe colombiano (Serie de Publicaciones Especiales, INVEMAR No. 20) (pp.119-148), Santa Marta: Colombia
Medellín-Mora, J., Escribano, R., \& Schneider, W. (2016). Community response of zooplankton to oceanographic changes (2002-2012) in the central/ southern upwelling system of Chile, Progress in Oceanography, 142, 17-29. https://doi.org/10.1016/j. pocean.2016.01.005

Michele, H., \& Foyo, M. (1976). Studies of Caribbean zooplankton. Rosenstiel School of Marine and Atmospheric Science, University of Miami, Miami, Florida, EE.UU.

Mooers, C., \& Maul, G. (1998). Intra-Americas sea circulation, coastal segment $(3, \mathrm{~W})$. In A. Robinson \& K. H. Brink (Eds.), The Sea (pp. 183-208). John Wiley and Sons, Inc., New York: EE.UU.

Moore, T. S., Matear, R. J., Marra, J., \& Clementson, L. (2007). Phytoplankton variability off the Western Australian Coast: Mesoscale eddies and their role in cross-shelf exchange. Deep Sea Research Part II: Topical Studies in Oceanography, 54(8), 943-960. https://doi.org/10.1016/j.dsr2.2007.02.006

Morales, C. E., Torreblanca, M., Hormazabal, S., CorreaRamírez, M., Nuñez, S., \& Hidalgo, P. (2010). Mesoscale structure of copepod assemblages in the coastal transition zone and oceanic waters off central-southern Chile, Progress in Oceanography, 84(3-4), 158-173. https://doi.org/10.1016/j. pocean.2009.12.001

Morrison, J. M., \& Nowlin, W. D. (1982). General distribution of water masses within the eastern Caribbean Sea during the winter of 1972 and fall of 1973, Journal of Geophysical Research: Oceans, 87(C6), 4207-4229. DOI: 10.1029/JC087iC06p04207

Nystuen, J. A., \& Andrade, C. A. (1993). Tracking mesoscale ocean features in the Caribbean Sea using Geosat altimetry. Journal of Geophysical Research, 98(C5), 8389-8394. DOI: 10.1029/93JC00125

Owre, M., \& Foyo, H. B. (1972). Studies on Caribbean zooplankton. Description of the program and results of the first cruise. Bulletin of Marine Science, 22(2), 483-521. (Recovered from http:// www.ingentaconnect.com/content/umrsmas/ bullmar/1972/00000022/00000002/art00013).

Park, T. S. (1970). Calanoid copepods from the Caribbean Sea and Gulf of Mexico. 2. New species and new records from plankton samples. Bulletin of Marine Science, 20(2), 72-546. (Recovered from http://www.ingentaconnect.com/content/umrsmas/ bullmar/1970/00000020/00000002/art00012).

Parson, T., Maita, Y., \& Lalli, C. (1984). A manual of chemical and biological methods for seawater samples analysis. Oxford, England: Pergamon Press.

Peterson, W. (1998). Life cycle strategies of copepods in coastal upwelling zones. Journal in Marine System, 15, 313-326. https://doi.org/10.1016/ S0924-7963(97)00082-1 
Posada, B., \& Henao, W. (2008). Diagnóstico de la erosión en la zona costera del Caribe colombiano. Serie de Publicaciones Especiales, INVEMAR No. 13. Santa Marta: Colombia.

Prairie, J., Sutherland, K., Nickols, K., \& Kaltenberg, A. (2012). Biophysical interactions in the plankton: A cross-scale review. Limnology and Oceanography. Fluids and Environments, 2(1), 121-145. DOI: $10.1215 / 21573689-1964713$

Rand, P. S., \& Hinch, S. G. (1998). Spatial patterns of zooplankton biomass in the northeast Pacific Ocean. Marine Ecology Progress Series, 171, 181186 (Recovered from http://www.int-res.com/articles/meps/171/m171p181.pdf)

Rangel-Buitrago, N., \& Idárraga-García, J. (2010). Geología general, morfología submarina y facies sedimentarias en el margen continental y los fondos oceánicos del mar Caribe colombiano. In INVEMAR (Eds.), Biodiversidad del Margen Continental del Caribe colombiano (Serie de Publicaciones Especiales, INVEMAR No. 20) (p. 29-51), Santa Marta: Colombia.

Restrepo, J. C., Ortíz, J. C., Pierini, J., Schrottke, K., Maza, M., Otero, L., \& Aguirre, J. (2014). Freshwater discharge into the Caribbean Sea from the rivers of Northwestern South America (Colombia): Magnitude, variability and recent changes. Journal of Hydrology, 509, 266-281. https://doi.org/10.1016/j. jhydrol.2013.11.045

Restrepo, J. D. (2008). Deltas de Colombia: morfodinámica y vulnerabilidad ante el Cambio Global. Primera Edición. Medellín, Colombia: EAFIT.

Restrepo, J. D., Zapata, P., Díaz, J. M., Garzón-Ferreira, J., \& García, C. (2006). Fluvial fluxes into the Caribbean Sea and their impact on coastal ecosystems: The Magdalena River, Colombia. Global and Planetary Change, 50 (1, 2), 33-49. https://doi. org/10.1016/j.gloplacha.2005.09.002

Richardson, A. J., \& Schoeman, D. S. (2004). Climate impact on plankton ecosystems in the Northeast Atlantic. Science, 305(5690), 1609-1612. DOI: $10.1126 /$ science 1100958
Robson, B., Barmuta, L., \& Fairweather, P. G. (2005). Methodological and conceptual issues in the search for a relationship between animal body-size distributions and benthic habitat architecture. Marine and Freshwater Research, 56(1), 1-11. DOI: 10.1071/ MF04210

Schott, F., \& Molinari, R. (1996). The western boundary circulation of the subtropical warmwatersphere. In W. Krauss (Ed.), The Warmwatersphere of the North Atlantic Ocean (pp. 229-252). Berlin: Gebrüder Bornträger.

Sheinbaum, J., Zavala, J., \& Candela, J. (1997). Modelación numérica del Golfo de México y Mar Caribe. Contribuciones a la Oceanografía Física en México, Monografía, 3. 12, 243-264.

Shin, Y. J., Rochet, M., Jennings, J. S., Field, J. G., \& Gislason, H. (2005). Using size-based indicators to evaluate the ecosystem effects of fishing. ICES Journal of Marine Science: Journal du Conseil, 62(3), 384-396.

Taylor, G. T., Muller-Karger, F. E., Thunell, R. C., Scranton, M. I., Astor, Y., Varela, R., Troccoli, L., Lorenzoni, ... Doherty, O. (2012). Ecosystem responses in the southern Caribbean Sea to global climate change. Proceedings of the National Academy of Sciences, 109(47), 19315-19320. doi: 10.1073/ pnas. 1207514109

Taylor, L. R. (1961). Aggregation, Variance and the Mean. Nature, 189(4766), 732-735. http://dx.doi. org/10.1038/189732a0.

Verheye, H., Hutchings, L., Huggett, J., \& Painting, S. (1992). Mesozooplankton dynamics in the Benguela ecosystem, with emphasis on the herbivorous copepods. South African Journal of Science, 12, 561-584. http://dx.doi.org/10.2989/02577619209504725

Williams, R. (1988). Spatial heterogeneity and niche differentiation in oceanic zooplankton. Hydrobiologia, 167(1), 151-159. DOI: 10.1007/BF00026301

Wüst, G. (1964). Stratification and circulation in the Antillean-Caribbean basins. New York, EE.UU: Columbia University Press. 